\title{
Characterization of Niobium-zirconium Mixed Oxide as a Novel Catalyst for Selective Catalytic Reduction of $\mathrm{NO}_{x}$
}

\author{
I. Cayirtepe $\cdot$ A. Naydenov $\cdot$ G. Ivanov • \\ M. Kantcheva
}

Received: 25 July 2009/Accepted: 28 August 2009/Published online: 11 September 2009

(C) Springer Science+Business Media, LLC 2009

\begin{abstract}
The performance of mixed niobium-zirconium oxide in the SCR of $\mathrm{NO}_{x}$ with propene in excess oxygen has been studied. The mixed oxide is prepared by impregnation of hydrated zirconia with acidic solution $(\mathrm{pH} 0.5)$ of peroxoniobium(V) complex, $\left[\mathrm{Nb}_{2}\left(\mathrm{O}_{2}\right)_{3}\right]^{4+}$, ensuring $\mathrm{ZrO}_{2}$ : $\mathrm{Nb}_{2} \mathrm{O}_{5}$ mole ratio of $6: 1$. The calcined sample (denoted as 25NbZ-P) has the structure of $\mathrm{Zr}_{6} \mathrm{Nb}_{2} \mathrm{O}_{17}$. According to the catalytic test, the conversion of $\mathrm{NO}_{x}$ over the $25 \mathrm{NbZ}-\mathrm{P}$ catalyst passes through a maximum at $220{ }^{\circ} \mathrm{C}$. Based on the in situ FT-IR results, a reaction mechanism is proposed with nitroacetone and NCO species as the key reaction intermediates. The results of the investigation show that the catalytic properties of the $\mathrm{Zr}_{6} \mathrm{Nb}_{2} \mathrm{O}_{17}$ solid solution could be of interest regarding the development of low-temperature catalyst for the SCR of $\mathrm{NO}_{x}$ with hydrocarbons.
\end{abstract}

Keywords Zirconia-niobia solid solution .

$\mathrm{C}_{3} \mathrm{H}_{6}$-SCR of $\mathrm{NO}_{x} \cdot$ Catalytic activity

In situ FT-IR spectroscopy $\cdot$ Reaction mechanism

\section{Introduction}

Nitrogen oxides, $\mathrm{NO}$ and $\mathrm{NO}_{2}$ (collectively referred as $\mathrm{NO}_{x}$ ) are harmful pollutants exhausted from mobile and stationary combustion engines. In the recent years, the $\mathrm{NO}_{x}$ emissions have been severely restricted especially for

I. Cayirtepe $\cdot$ M. Kantcheva ( $\square)$

Department of Chemistry, Bilkent University,

06800 Bilkent, Ankara, Turkey

e-mail: margi@fen.bilkent.edu.tr

A. Naydenov · G. Ivanov

Institute of General and Inorganic Chemistry,

BAS, 1113 Sofia, Bulgaria automobiles. Diesel and lean-burn gasoline engines are outstanding with respect to fuel efficiency [1, 2]. However, they emit more $\mathrm{NO}_{x}$ when compared to conventional gasoline engines equipped with a three-way catalyst. The exhaust typical for diesel and lean-burn gasoline engines contains an excess of oxygen and this requires a catalytic process that allows for successful reduction of $\mathrm{NO}_{x}$ in competition with the reduction of oxygen. Reduction of $\mathrm{NO}_{x}$ using either the residual hydrocarbons or on-board fuel would be the most ideal technology. However, the traditional materials developed for the selective reduction of $\mathrm{NO}_{x}$ with hydrocarbons (HC-SCR) do not show sufficient activities under the conditions of lean exhaust especially at low temperatures $\left(<150-250{ }^{\circ} \mathrm{C}\right)$ [3-6]. There is still interest in finding a direct HC-SCR catalyst, which possesses high activity in the low-temperature range, good hydrothermal stability and good sulfur tolerance.

Despite of the fact that niobium-containing materials show potential applications in various oxidation and acidcatalyzed reactions $[7,8]$, a little attention has been given to the performance of these catalysts in the SCR of $\mathrm{NO}_{x}$. Regarding the reduction of NO with hydrocarbons in excess oxygen, Hinode and co-workers $[9,10]$ reported that niobium oxide supported on titania is active in the reaction with ethene and propene showing maximum NO conversion of 30 and $62 \%$, respectively, at about $375{ }^{\circ} \mathrm{C}$. Using a mechanical mixture of $\mathrm{Nb} / \mathrm{TiO}_{2}$ and $\mathrm{Mn}_{2} \mathrm{O}_{3}$ improves the activity in the SCR with propene and lowers the temperature of maximum $\mathrm{NO}$ conversion to $200-300{ }^{\circ} \mathrm{C}$ [11]. Kikuchi and Kumagai investigated the catalytic performance of Nb-promoted $\mathrm{Ag} / \mathrm{Al}_{2} \mathrm{O}_{3}$ and $\mathrm{Co} / \mathrm{Al}_{2} \mathrm{O}_{3}$ catalysts in the SCR of $\mathrm{NO}_{x}$ in diesel engine exhaust using light gas oil as reductant $[11,12]$. The catalytic activity of the promoted catalysts was higher than that of the un-promoted ones and the adsorbed amount of sulfur was lower on the 
$\mathrm{Nb}$-containing catalysts. It has been reported that the deposition of niobium on the surface of alumina lowers the concentration of basic sites [13] which should result in improved resistance to $\mathrm{SO}_{2}$ poisoning.

Ziolek and co-workers investigated the possibility for application of Pt-promoted niobiosilicate ordered mesoporous materials (NbMCM-41) as $\mathrm{NO}_{x}$ storage (NSR) and $\mathrm{C}_{3} \mathrm{H}_{6}-\mathrm{SCR}$ catalysts [14-16]. The presence of niobium in the MCM-41 matrix enhanced the oxidative properties of the catalyst and NO was adsorbed in the form of nitrite/ nitrate species $[14,15]$. However, the latter species were bound strongly to the surface which hindered their further interaction with propene. The introduction of zirconium near niobium in the MCM-41 matrix weakened the bond of the nitrites/nitrates with the niobium species and enhanced the SCR selectivity [16]. Based on the results of in situ FT-IR study we proposed recently that the $\mathrm{Pd}$-promoted $\mathrm{Zr}_{6} \mathrm{Nb}_{2} \mathrm{O}_{17}$ solid solution has the potential of a catalyst for the selective reduction of NO with methane [17]. The Pd-free mixed oxide is thermally stable [18] and has high permanent Brønsted acidity [17].

The analysis of the literature data reveals that the oxidebased catalysts containing niobium may represent an alternative to the current catalytic materials for HC-SCR of $\mathrm{NO}_{x}$. The aim of this paper was to test the activity of $\mathrm{Zr}_{6} \mathrm{Nb}_{2} \mathrm{O}_{17}$ solid solution in the SCR of $\mathrm{NO}_{x}$ with propene. In order to determine the reaction route, we carried out in situ FTIR investigations of the adsorption and co-adsorption of the reagents followed by their interactions at various temperatures. According to our knowledge, there are no reports dealing with the DeNOx properties as well as with NO interaction with propene in the presence of oxygen on such kind of a material.

\section{Experimental}

The mixed zirconia-niobia was prepared by impregnation of hydrated zirconia with acidic solution $(\mathrm{pH} 0.5)$ of peroxoniobium(V) complex, $\left[\mathrm{Nb}_{2}\left(\mathrm{O}_{2}\right)_{3}\right]^{4+}$, ensuring $\mathrm{ZrO}_{2}: \mathrm{Nb}_{2} \mathrm{O}_{5}$ mole ratio of $6: 1$. After drying, the material was calcined at $600{ }^{\circ} \mathrm{C}$ for $2 \mathrm{~h}$. The BET surface area of the calcined material (denoted as 25NbZ-P) was $42 \mathrm{~m}^{2} / \mathrm{g}$. According to XRD the obtained sample has the structure of $\mathrm{Zr}_{6} \mathrm{Nb}_{2} \mathrm{O}_{17}$ [17]. The adsorption of 2,6-dimethylpyridine on the $25 \mathrm{NbZ}$ $\mathrm{P}$ sample revealed the presence of strong Brønsted acidity. Details about the method of preparation and characterization of the surface acidity are given elsewhere [17].

The catalytic test of $\mathrm{NO}_{x}$ reduction by propene was carried out in a tubular flow reactor (quartz glass) with an internal diameter of $6.0 \mathrm{~mm}$. The catalyst sample was loaded in the form of particles with irregular shape and size of $0.6-1.2 \mathrm{~mm}$. The gas analysis was performed using on-line analyzers as follows: $\mathrm{NO} / \mathrm{NO}_{2} / \mathrm{NO}_{x}$ (Environment S.A., Model $31 \mathrm{M}$ ), $\mathrm{CO} / \mathrm{CO}_{2} / \mathrm{O}_{2}$ (Maihak), THC (ThermoFID). Gas supply section was based on mass-flow controllers manufactured by Bronkhorst. The catalyst was tested at GHSV of $10,000 \mathrm{~h}^{-1}$. The reaction mixture used contained $245 \mathrm{ppm}$ of $\mathrm{NO}_{x}\left(\mathrm{NO} / \mathrm{NO}_{2}=1.77\right), 504 \mathrm{ppm}$ $\mathrm{C}_{3} \mathrm{H}_{6}, 9$ vol. $\%$ of oxygen and nitrogen for balance to 100 vol. \%. The steady-state test was made upon step-wise increase of the reaction temperature and holding at each temperature $(\sim 1.5 \mathrm{~h})$ to reach a constant conversion value. The conversion degrees of $\mathrm{NO}_{x}$ (taken as a measure of the catalytic activity) and propene were calculated using the inlet and outlet concentrations.

The FT-IR spectra were recorded using a Bomem Hartman \& Braun MB-102 model FT-IR spectrometer with a liquid-nitrogen cooled MCT detector at a resolution of $4 \mathrm{~cm}^{-1}$ (128 scans). The self-supporting discs $(\sim 0.01$ $\mathrm{g} / \mathrm{cm}^{2}$ ) were activated in the IR cell by heating for $1 \mathrm{~h}$ in a vacuum at $450{ }^{\circ} \mathrm{C}$, and in oxygen (100 mbar, passed through a trap cooled in liquid nitrogen) at the same temperature, followed by evacuation for $1 \mathrm{~h}$ at $450{ }^{\circ} \mathrm{C}$. The experiments were carried out under static conditions. The spectra of the adsorbed compounds were obtained by subtracting the spectra of the activated samples from the spectra recorded. The sample spectra were also gas-phase corrected. The gases NO (99.9\%), and $\mathrm{C}_{3} \mathrm{H}_{6}$ (99.9) used in the in situ FT-IR experiments were supplied by Air Products.

\section{Results}

\subsection{Catalytic Activity}

Figure 1 shows the $\mathrm{NO}_{x}$ reduction activity of $25 \mathrm{NbZ}-\mathrm{P}$ catalyst at various temperatures. The $\mathrm{NO}_{x}$ conversion (Fig. 1, curve (a)) reaches $62 \%$ at $220{ }^{\circ} \mathrm{C}$ and than decreases as the combustion of propene becomes predominant (Fig. 1, curve (b)). The conversion of $\mathrm{C}_{3} \mathrm{H}_{6}$ is close to $100 \%$ at $250{ }^{\circ} \mathrm{C}$. The catalyst displays stable activity at the temperature of maximum $\mathrm{NO}_{x}$ conversion (the duration of catalytic activity tests was limited to $10 \mathrm{~h}$ ). The results show that the catalytic properties of the $25 \mathrm{NbZ}$ $\mathrm{P}$ sample could be of interest regarding the development of efficient HC-SCR catalyst that could be active at typical diesel exhaust-gas temperatures $\left(\leq 300^{\circ} \mathrm{C}\right)$.

\subsection{FT-IR Spectroscopic Measurements}

\subsubsection{Co-adsorption of $\mathrm{NO}+\mathrm{O}_{2}$ on the 25NbZ-P Catalyst}

Figure $2 \mathrm{a}$ shows the spectrum of the gas phase detected at room temperature immediately after the admission of a gas mixture containing 10 mbar of $\mathrm{NO}$ and $20 \mathrm{mbar}$ of $\mathrm{O}_{2}$ to the 


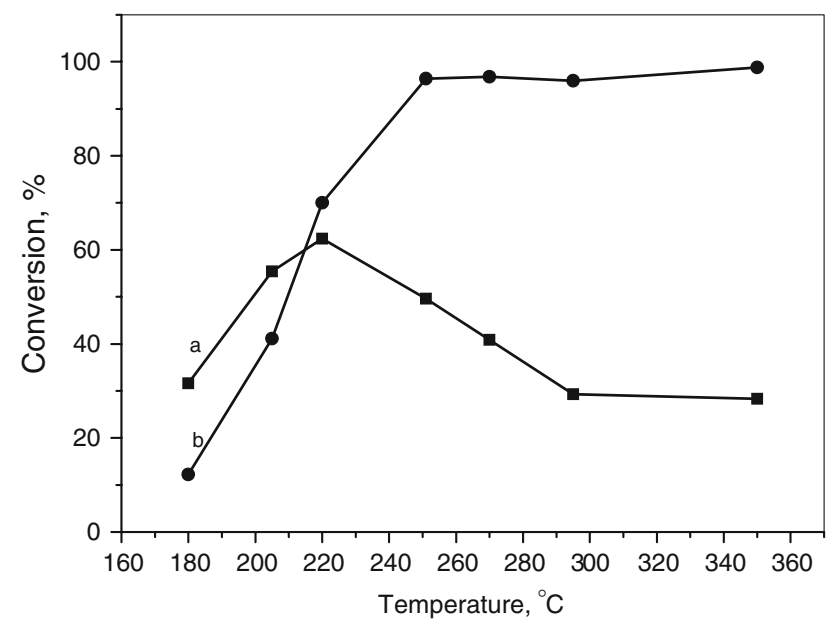

Fig. 1 Catalytic activity for $\mathrm{NO}_{x}$ reduction with propene $(a)$ and conversion of propene into $\mathrm{CO}_{2}(b)$ over the $25 \mathrm{NbZ}-\mathrm{P}$ catalysts at various temperatures. Reaction conditions: $245 \mathrm{ppm} \mathrm{NO}_{x}(\mathrm{NO} /$ $\left.\mathrm{NO}_{2}=1.77\right), 504$ ppm $_{3} \mathrm{H}_{6}, 9$ vol. $\% \mathrm{O}_{2}, \mathrm{GHSV}=10,000 \mathrm{~h}^{-1}$ )

empty IR cell (spectrum (a)). Gaseous $\mathrm{NO}_{2}$ (band at $1,617 \mathrm{~cm}^{-1}$ ) and $\mathrm{N}_{2} \mathrm{O}_{4}$ (bands at 1,758 and $1,264 \mathrm{~cm}^{-1}$ ) are formed by the reaction of $\mathrm{NO}$ with $\mathrm{O}_{2}$ in the gas phase $\left(2 \mathrm{NO}+\mathrm{O}_{2}=2 \mathrm{NO}_{2}\right)$. The concentrations of $\mathrm{NO}$ and $\mathrm{NO}_{2}$ do not change appreciably after $30 \mathrm{~min}$. The spectrum taken immediately after the exposure of the 25NbZ-P sample at room temperature to the same gas mixture (Fig. 2a, spectrum (b)), in addition to the absorptions of $\mathrm{NO}_{2}$ and $\mathrm{N}_{2} \mathrm{O}_{4}$, contains a pair of bands at 1,832 and $1,305 \mathrm{~cm}^{-1}$ corresponding to the $v(\mathrm{~N}=\mathrm{O})$ and $v_{\mathrm{s}}\left(\mathrm{NO}_{2}\right)$ modes of asymmetric $\mathrm{N}_{2} \mathrm{O}_{3}$ [19]. Since the latter compound was not observed when mixing $\mathrm{NO}$ and $\mathrm{O}_{2}$ in the empty IR cell (Fig. 2a, spectrum (a)), it is evident that the 25NbZ-P sample favors the comproportionation of $\mathrm{NO}$ and $\mathrm{NO}_{2}$ to $\mathrm{N}_{2} \mathrm{O}_{3}$. The contact of the sample for $30 \mathrm{~min}$ with the gas mixture leads to strong increase in the amounts of $\mathrm{NO}_{2}$ and $\mathrm{N}_{2} \mathrm{O}_{4}$ and significant lowering of the concentrations of $\mathrm{NO}$ and $\mathrm{N}_{2} \mathrm{O}_{3}$ (Fig. 2a, spectrum (c)). This result indicates that the 25NbZ$\mathrm{P}$ sample promotes the oxidation of $\mathrm{NO}$ at room temperature. The spectra of the sample obtained immediately (Fig. 2b, spectrum (b)) and $30 \mathrm{~min}$ after the admission of the $\mathrm{NO}+\mathrm{O}_{2}$ mixture (Fig. 2b, spectrum (c)) contain bands at $1,900-1,885$ and $1,755-1,752 \mathrm{~cm}^{-1}$ which are attributed to adsorbed $\mathrm{N}_{2} \mathrm{O}_{3}$ and $\mathrm{N}_{2} \mathrm{O}_{4}$, respectively [20, 21]. The broad absorption with maximum at $2,187 \mathrm{~cm}^{-1}$ is typical of $\mathrm{NO}^{+}$ species [20-22]. The bands at 1,651,1,217, and $1,004 \mathrm{~cm}^{-1}$ are assigned to the $v(\mathrm{~N}=\mathrm{O}), v_{\mathrm{as}}\left(\mathrm{NO}_{2}\right)$ and $v_{\mathrm{s}}\left(\mathrm{NO}_{2}\right)$ stretching vibrations of bridged nitrates, whereas the bands at 1,585, 1,270 , and $1,020 \mathrm{~cm}^{-1}$ indicate the formation of bidentate $\mathrm{NO}_{3}{ }^{-}$species [20-22]. The shoulder at about $1,530 \mathrm{~cm}^{-1}$ (Fig. 2b, spectrum (c)) decreases in intensity during the outgassing (Fig. 2b, spectrum (d)). This absorption is due most likely to the $v_{\text {as }}\left(\mathrm{NO}_{2}\right)$ mode of adsorbed $\mathrm{N}_{2} \mathrm{O}_{3}$ [20-22] which is superimposed to the $v(\mathrm{~N}=\mathrm{O})$ stretching vibration of a second bidentate nitrate. The $v_{\mathrm{s}}\left(\mathrm{NO}_{2}\right)$ modes of the latter species is positioned at $1,030 \mathrm{~cm}^{-1}$, whereas the $v_{\text {as }}\left(\mathrm{NO}_{2}\right)$ band should fall between 1,350 and $1,200 \mathrm{~cm}^{-1}$ and cannot be resolved. Since the $\mathrm{Zr}^{4+}$ ions are considered to be irreducible, the $\mathrm{Nb}^{5+}$ species should play the role of oxidizing centers in the processes of $\mathrm{NO}_{2} / \mathrm{N}_{2} \mathrm{O}_{4}$ and surface
Fig. 2 a Gas phase spectra recorded at room temperature immediately after the admission of a (10 mbar NO + 20 mbar $\mathrm{O}_{2}$ ) mixture to the empty IR cell (a), after the introduction of the same gas mixture immediately to the IR cell in the presence of the $25 \mathrm{NbZ}-\mathrm{P}$ catalyst $(b)$, and after $30 \min (c)$. b FT-IR spectra of adsorbed $\mathrm{NO}_{x}$ species taken immediately during the exposure of the $25 \mathrm{NbZ}-\mathrm{P}$ catalyst to the same gas mixture at room temperature $(b)$, after 30 min $(c)$ and upon dynamic evacuation for $30 \mathrm{~min}(d)$
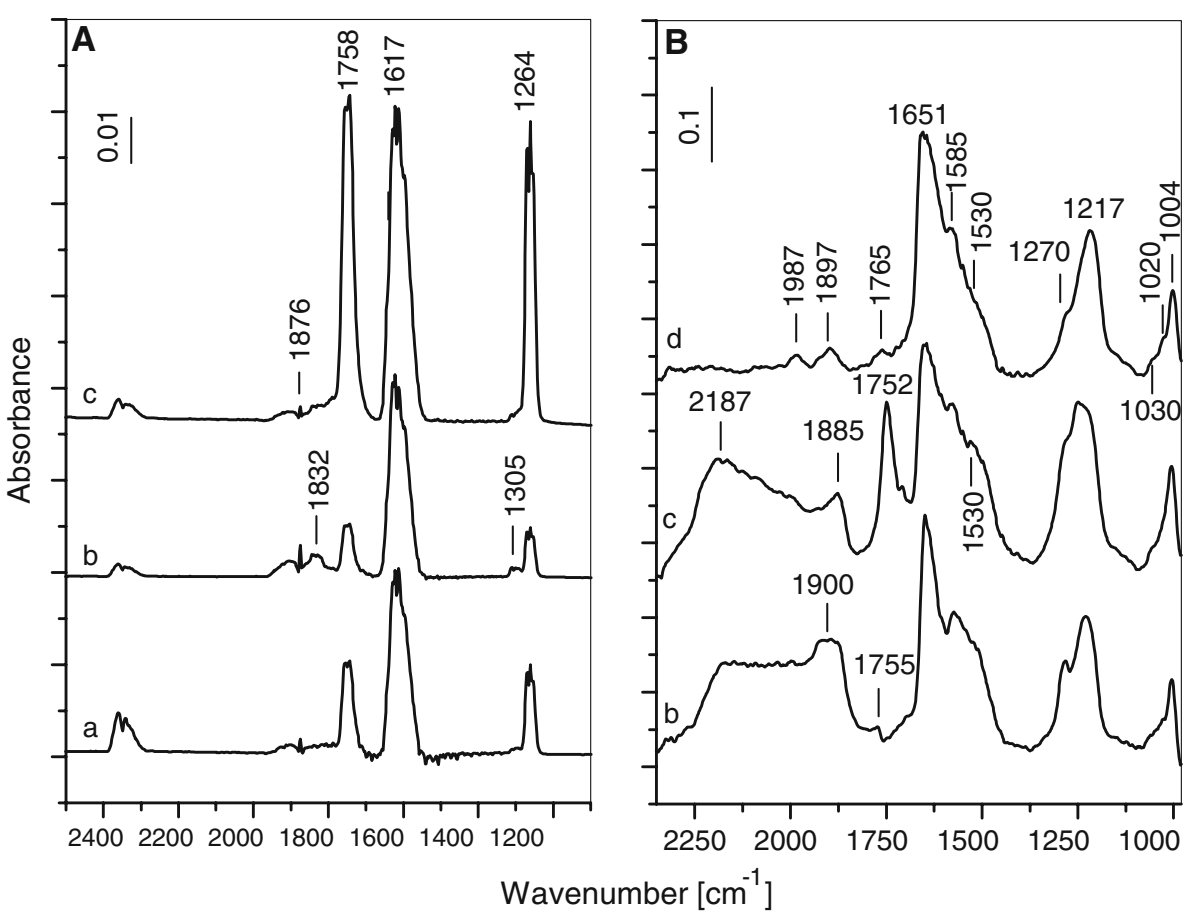
nitrate generation. Another possibility for the formation of surface $\mathrm{NO}_{3}{ }^{-}$species is through self-ionization of $\mathrm{NO}_{2}$ on surface Lewis acid-base pairs according to the reaction [20-22]:

$2 \mathrm{NO}_{2} \rightarrow \mathrm{NO}_{3}^{-}+\mathrm{NO}^{+}$

In general, the $\mathrm{NO}_{2}, \mathrm{~N}_{2} \mathrm{O}_{4}$, and $\mathrm{N}_{2} \mathrm{O}_{3}$ molecules are weakly adsorbed and they can be removed easily by evacuation [20-22]. Therefore, the weak bands at 1,987, 1,897 , and $1,764 \mathrm{~cm}^{-1}$ observed in the spectrum upon prolonged evacuation (Fig. 2b, spectrum (d)) are attributed to combination modes of the nitrate species [20, 22]. The $\mathrm{NO}^{+}$species disappear upon the evacuation. The assignment of the absorption bands observed during the $\mathrm{NO}+\mathrm{O}_{2}$ coadsorption on the $25 \mathrm{NbZ}-\mathrm{P}$ sample at room temperature is proposed in Table 1.

The thermal stability of the nitrate species adsorbed on the $25 \mathrm{NbZ}-\mathrm{P}$ sample was investigated by heating the isolated IR cell in the $25-350{ }^{\circ} \mathrm{C}$ temperature range for $15 \mathrm{~min}$ at each temperature (Fig. 3). A gradual decrease in the intensities of the nitrate bands is observed with the increase in the temperature (Fig. 3a). At $350{ }^{\circ} \mathrm{C}$ the $\mathrm{NO}_{3}{ }^{-}$ species almost vanish. The gas phase spectra (Fig. 3b) show that the product of thermal decomposition of the nitrates is $\mathrm{NO}_{2}$. It should be noted that the thermal stability of surface nitrates formed on pure zirconia is significant higher that that of the nitrate species adsorbed on the 25NbZ-P sample. In the former case the $\mathrm{NO}_{3}{ }^{-}$species resist the dynamic evacuation at $400{ }^{\circ} \mathrm{C}$ and under these conditions they are present in significant amount on the surface of zirconia [22]. This indicates that the introduction of niobium(V) to zirconia lowers the thermal stability of the surface nitrates.

Table 1 Assignments of the absorption bands in the spectra observed during the $\mathrm{NO}+\mathrm{O}_{2}$ coadsorption on the $25 \mathrm{NbZ}-\mathrm{P}$ catalyst at room temperature

\begin{tabular}{lll}
\hline Species & Band position $\left(\mathrm{cm}^{-1}\right)$ & Vibration \\
\hline $\mathrm{NO}^{+}$ & 2,187 & $v(\mathrm{NO})$ \\
$\mathrm{N}_{2} \mathrm{O}_{3}$ (ads) & 1,885 & $v(\mathrm{~N}=\mathrm{O})$ \\
& 1,530 & $v_{\text {as }}\left(\mathrm{NO}_{2}\right)$ \\
$\mathrm{N}_{2} \mathrm{O}_{4}$ (ads) & 1,752 & $v_{\text {as }}\left(\mathrm{NO}_{2}\right)$ \\
${\text { Bridged } \mathrm{NO}_{3}{ }^{-}}^{-}$ & 1,651 & $v(\mathrm{~N}=\mathrm{O})$ \\
& 1,217 & $v_{\text {as }}\left(\mathrm{NO}_{2}\right)$ \\
& 1,004 & $v_{\mathrm{s}}\left(\mathrm{NO}_{2}\right)$ \\
& $1,987,1,897$ & $v_{\mathrm{s}}\left(\mathrm{NO}_{2}\right)+\delta(\mathrm{ONO})$ \\
Bidentate $\mathrm{NO}_{3}{ }^{-}$ & $1,585,1,530$ & $v(\mathrm{~N}=\mathrm{O}))$ \\
(two types) & 1,270 & $v_{\text {as }}\left(\mathrm{NO}_{2}\right)$ \\
& $1,020,1,030$ & $v_{\mathrm{s}}\left(\mathrm{NO}_{2}\right)$ \\
& 1,765 & $v_{\mathrm{s}}\left(\mathrm{NO}_{2}\right)+\delta(\mathrm{ONO})$ \\
\hline
\end{tabular}

\subsubsection{Co-adsorption of $\left(\mathrm{C}_{3} \mathrm{H}_{6}+\mathrm{O}_{2}\right)$ on the $25 \mathrm{NbZ}-\mathrm{P}$ Catalyst}

Figure 4 shows the development of the spectra in the 25-350 ${ }^{\circ} \mathrm{C}$ temperature range obtained during the contact of the catalyst with a gas mixture containing 3 mbar of $\mathrm{C}_{3} \mathrm{H}_{6}$ and 10 mbar of $\mathrm{O}_{2}$. The bands at 1,619 and $1,451 \mathrm{~cm}^{-1}$ observed in the spectrum detected at room temperature (Fig. 4, spectrum (a)) are characteristic of propene adsorbed on oxide surfaces and correspond to the $v(\mathrm{C}=\mathrm{C})$ and $\delta_{\text {as }}\left(\mathrm{CH}_{3}\right)$ modes, respectively [23]. The weak absorption at $2,980-2,950 \mathrm{~cm}^{-1}$ is assigned to the $\mathrm{CH}_{3}$ stretching vibrations. Heating the closed IR cell at $100{ }^{\circ} \mathrm{C}$ for 15 min (Fig. 4, spectrum (b)), causes decrease in the intensity of the bands at 1,619 and $1,451 \mathrm{~cm}^{-1}$ of adsorbed propene and appearance of weak bands at 1,104 and $1,010 \mathrm{~cm}^{-1}$. The shape of the absorption in the $\mathrm{CH}_{3}$ stretching region has changed. At $150{ }^{\circ} \mathrm{C}$ (Fig. 4, spectrum (c)) the adsorbed propene disappears almost completely. The bands at 2,982 $\left[v_{\text {as }}\left(\mathrm{CH}_{3}\right)\right]$ and $2,936 \mathrm{~cm}^{-1}\left[v_{\mathrm{s}}\left(\mathrm{CH}_{3}\right)\right]$ detected under these conditions (Fig. 4, spectrum (c)) are characteristic of two types of isopropoxy species with the $v(\mathrm{C}-\mathrm{O})$ modes at 1,104 and $1,010 \mathrm{~cm}^{-1}$, respectively [24-30]. At $200{ }^{\circ} \mathrm{C}$ (Fig. 4, spectrum (d)), new absorptions at 1,669 and $1,560 \mathrm{~cm}^{-1}$ are observed. The former band is attributed to the $v(\mathrm{C}=\mathrm{O})$ stretching of adsorbed acetone [25-28, 31] which is formed at the expense of the isopropoxy species. This assignment is supported by the observation that the activation of propene over catalysts containing Brønsted acid sites proceeds through formation of surface isopropoxides, which are transformed into acetone followed by oxidation of the latter molecule to acetate species $[25,26]$ - the weak band at $1,560 \mathrm{~cm}^{-1}$. When the temperature is raised to $250{ }^{\circ} \mathrm{C}$ (Fig. 4, spectrum (e)), strong absorptions emerge at 1,590, 1,538, 1,444, and $1,410 \mathrm{~cm}^{-1}$ (shoulder), which are assigned to the COO stretching vibrations of two types of acetate species [26-28, 31]. The assignment of the absorption bands is summarized in Table 2.

\subsubsection{Reactivity of the Surface Species Formed upon Room-temperature Adsorption of $\mathrm{NO}+\mathrm{C}_{3} \mathrm{H}_{6}+\mathrm{O}_{2}$ Mixture on the 25NbZ-P Catalyst}

The 25NbZ-P sample was exposed to a gaseous mixture containing 18 mbar $\mathrm{NO}+3$ mbar $_{3} \mathrm{H}_{6}+10$ mbar $\mathrm{O}_{2}$ at room temperature for $20 \mathrm{~min}$ followed by evacuation for $10 \mathrm{~min}$. The spectrum obtained under these conditions is shown in Figs. 5a, b, spectrum (a). The broad absorption between 3,600 and $2,500 \mathrm{~cm}^{-1}$ is typical of $\mathrm{H}$-bonded hydroxyls and indicates that the oxidation of propene has occurred already at room temperature. The weak bands at 2,990 and $2,935 \mathrm{~cm}^{-1}$ are attributed to the $v_{\text {as }}\left(\mathrm{CH}_{3}\right)$ and 
Fig. 3 a FT-IR spectra of the 25NbZ-P catalyst taken after the adsorption of a $(10 \mathrm{mbar}$ $\mathrm{NO}+20$ mbar $\mathrm{O}_{2}$ ) mixture to the IR cell for $30 \mathrm{~min}$ at room temperature followed by evacuation for $30 \mathrm{~min}(a)$, and after heating the isolated IR cell for $15 \mathrm{~min}$ at $100{ }^{\circ} \mathrm{C}(b)$, $150{ }^{\circ} \mathrm{C}(c), 250{ }^{\circ} \mathrm{C}(d)$ and $350{ }^{\circ} \mathrm{C}(e)$. b Gas phase spectra collected at $100{ }^{\circ} \mathrm{C}(b), 150{ }^{\circ} \mathrm{C}$ (c), $250{ }^{\circ} \mathrm{C}(d)$ and $350{ }^{\circ} \mathrm{C}(e)$
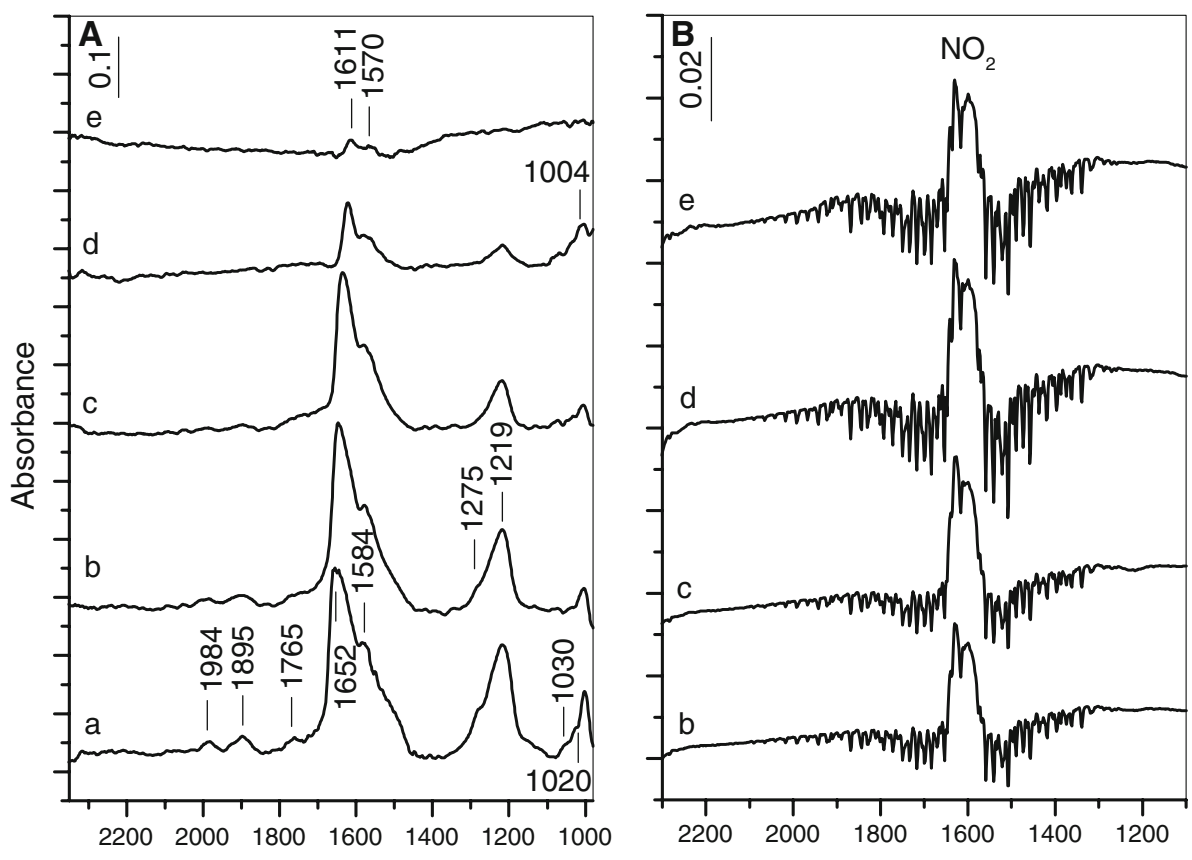

Wavenumber $\left[\mathrm{cm}^{-1}\right]$
$v_{\mathrm{s}}\left(\mathrm{CH}_{3}\right)$ stretching vibrations of adsorbed propene and partially oxidized derivatives of the hydrocarbon. The bands in the $1,800-1,000 \mathrm{~cm}^{-1}$ region overlap heavily and it is difficult to propose an unambiguous assignment. Based on the spectra of adsorbed $\mathrm{NO}_{3}{ }^{-}$species (Fig. 2), the absorptions at 1,654, 1,234, 1,570, and 1,275 $\mathrm{cm}^{-1}$ are all assignable to bridged and bidentate nitrates. However, judging from the relative intensities of the nitrate bands at 1,275 and $1,234 \mathrm{~cm}^{-1}$, it seems that the population of the bidentate nitrates at 1,570 and $1,275 \mathrm{~cm}^{-1}$ formed in the $\mathrm{NO}+\mathrm{C}_{3} \mathrm{H}_{6}+\mathrm{O}_{2}$ experiment is higher than that generated during the $\mathrm{NO}+\mathrm{O}_{2}$ co-adsorption (compare with Fig. 2). This indicates that there is a competition between the nitrate species and other surface compounds for the same adsorption sites. The absorption at $1,610 \mathrm{~cm}^{-1}$ can be attributed to both bending mode of adsorbed water and $v_{\mathrm{as}}(\mathrm{COO})$ stretching vibration of adsorbed acetate [26-28, 31]. Most likely, two types of acetate species are formed which is supported by the presence of two bands at 1,454 and $1,420 \mathrm{~cm}^{-1}$ corresponding to their $v_{\mathrm{s}}(\mathrm{COO})$ modes [26-28, 31]. The $v_{\text {as }}(\mathrm{COO})$ stretching vibration of the second acetate species is probably covered by the nitrate band at $1,570 \mathrm{~cm}^{-1}$. The absorption at $1,725 \mathrm{~cm}^{-1}$ is characteristic of a carbonyl moiety and is attributed to nitroacetone. Arguments for this assignment are given below. Here it should be noted that nitroketones exhibit absorptions at 1,730, 1,560, and $1,380 \mathrm{~cm}^{-1}$ corresponding to the $v(\mathrm{C}=\mathrm{O}), v_{\mathrm{as}}\left(\mathrm{NO}_{2}\right)$ and $v_{\mathrm{s}}\left(\mathrm{NO}_{2}\right)$ modes [32]. The antisymmetric $\mathrm{NO}_{2}$ stretching vibration of nitroacetone is covered by the nitrate band at $1,570 \mathrm{~cm}^{-1}$ and cannot be resolved. The band at $1,139 \mathrm{~cm}^{-1}$ is assigned to the $\delta(\mathrm{CCC})$ mode of the nitroketone. The weak absorptions at 1,098 and $1,010 \mathrm{~cm}^{-1}$ are attributed to the $v(\mathrm{C}-\mathrm{O})$ modes of adsorbed isopropoxides [24-30]. The latter absorption has a contribution from the $v_{\mathrm{s}}\left(\mathrm{NO}_{2}\right)$ stretching vibration of the bridged nitrates. The broad band at $2,290 \mathrm{~cm}^{-1}$ is typical of NCO species adsorbed on oxide surfaces [33-38]. An argument in support of the assignment of the absorption at $2,290 \mathrm{~cm}^{-1}$ to a N,C-containing species is the absence of this feature in the spectra obtained during the $\mathrm{NO}+\mathrm{O}_{2}$ coadsorption (see Fig. 2b, spectrum (d) and Fig. 3a). The formation of NCO species could be associated with the transformation of nitroacetone. Weingand et al. [38] observed generation of $-\mathrm{C}=\mathrm{O}$-containing compounds at $100{ }^{\circ} \mathrm{C}$ during the interaction between propene and nitrate species adsorbed on $\mathrm{WO}_{3}-\mathrm{ZrO}_{2}$. They suggested that the $-\mathrm{C}=\mathrm{O}$-containing species are converted into isocyanates with the participation of surface nitrates.

Finally, the fact that no partially oxidized hydrocarbon species were observed at room temperature during the $\mathrm{C}_{3} \mathrm{H}_{6}+\mathrm{O}_{2}$ experiment (Fig. 4, spectrum (a)), indicates that the formation of surface nitrates and/or gaseous $\mathrm{NO}_{2}$ during the room-temperature adsorption of $\mathrm{NO}+\mathrm{C}_{3} \mathrm{H}_{6}+$ $\mathrm{O}_{2}$ mixture facilitates the activation of propene.

Heating the sample for $15 \mathrm{~min}$ at $100{ }^{\circ} \mathrm{C}$ causes the following changes:

(1) Increase in the concentrations of partially oxidized hydrocarbons (Fig. 5b, spectrum (b)), which is evident by the enhancement of the intensities of the bands corresponding to the isopropoxides $\left(1,098 \mathrm{~cm}^{-1}\right)$, acetates 


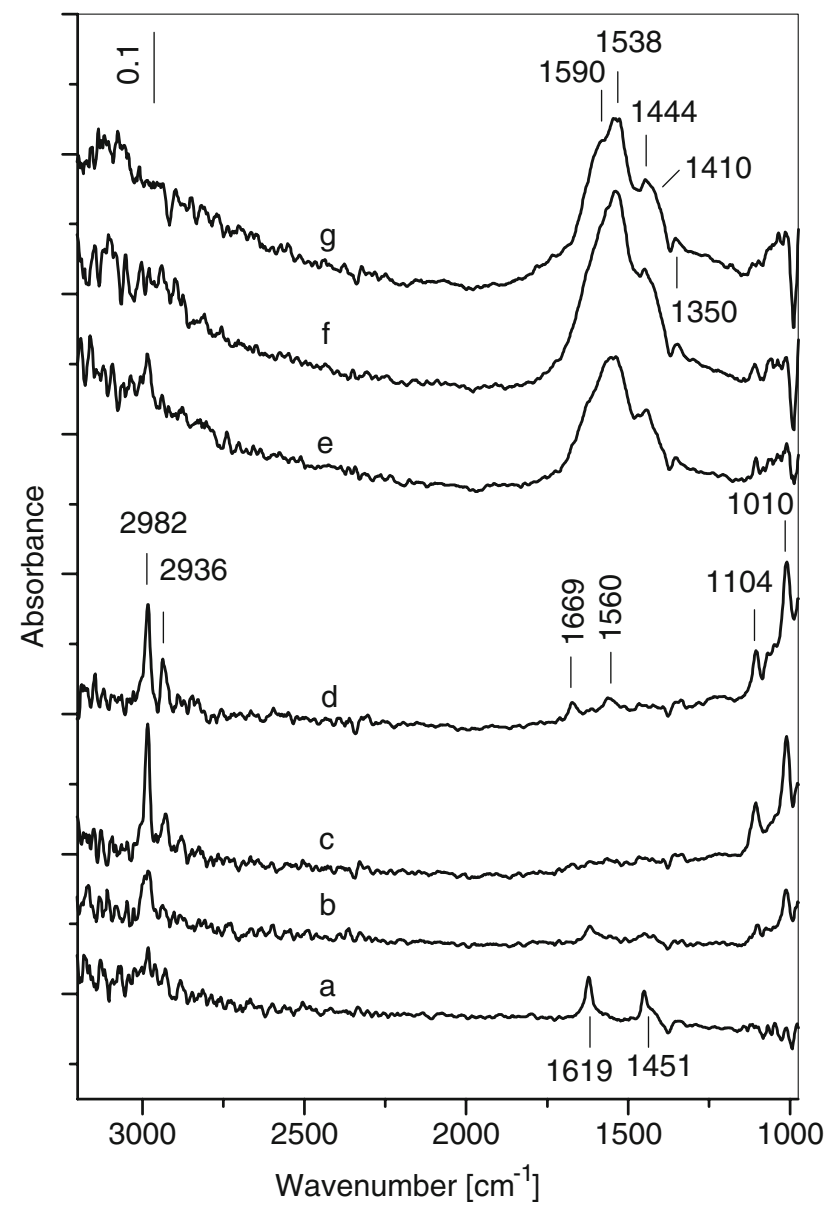

Fig. 4 FT-IR spectra collected during the exposure of the 25NbZ-P catalyst to a $\left(3\right.$ mbar $\mathrm{C}_{3} \mathrm{H}_{6}+10$ mbar $\left.\mathrm{O}_{2}\right)$ mixture for $15 \mathrm{~min}$ at room temperature $(a)$ followed by heating the isolated IR cell for 15 min at $100{ }^{\circ} \mathrm{C}(b), 150{ }^{\circ} \mathrm{C}(c), 200{ }^{\circ} \mathrm{C}(d), 250{ }^{\circ} \mathrm{C}(e), 300{ }^{\circ} \mathrm{C}$ $(f)$ and $350{ }^{\circ} \mathrm{C}(g)$

Table 2 Assignments of the adsorption bands in the spectra observed during the high-temperature adsorption of $\mathrm{C}_{3} \mathrm{H}_{6}+\mathrm{O}_{2}$ mixture on the $25 \mathrm{NbZ}-\mathrm{P}$ catalyst

\begin{tabular}{lll}
\hline Species & Band position $\left(\mathrm{cm}^{-1}\right)$ & Vibration \\
\hline $\mathrm{C}_{3} \mathrm{H}_{6}$ (ads) & 1,619 & $v(\mathrm{C}=\mathrm{C})$ \\
& 1,451 & $\delta_{\text {as }}\left(\mathrm{CH}_{3}\right)$ \\
Isopropoxide (two types) & $2,982,2,936$ & $v_{\text {as }}\left(\mathrm{CH}_{3}\right), v_{\mathrm{s}}\left(\mathrm{CH}_{3}\right)$ \\
& $1,104,1,010$ & $v(\mathrm{C}-\mathrm{O})$ \\
Acetone (ads) & 1,669 & $v(\mathrm{C}=\mathrm{O})$ \\
$\mathrm{CH}_{3} \mathrm{COO}^{-}$(two types) & $1,590,1,560-1,538$ & $v_{\text {as }}(\mathrm{COO})$ \\
& $1,410,1,444$ & $v_{\mathrm{s}}(\mathrm{COO})$ \\
& 1,350 & $\delta(\mathrm{CH})$ \\
\hline
\end{tabular}

$\left(1,454\right.$ and $\left.1,420 \mathrm{~cm}^{-1}\right)$ and nitroacetone (1,725 and $\left.1,139 \mathrm{~cm}^{-1}\right)$. This is accompanied by the appearance of a pronounced absorption at $2,880 \mathrm{~cm}^{-1}$ typical of $\mathrm{CH}_{2}$ stretching vibration (Fig. 5a, spectrum (b)). The fact that there is enhancement in the concentration of partially oxidized hydrocarbons (isopropoxides, nitroacetone, acetates) at $100{ }^{\circ} \mathrm{C}$ suggests the presence of adsorbed propene at room temperature.

(2) Decrease in the concentration of the surface nitrates and isocyanates (the $v_{\text {as }}(\mathrm{NCO})$ band is shifted to 2,260 $\mathrm{cm}^{-1}$ ) which is accompanied by formation of $\mathrm{NO}_{2}$ and $\mathrm{N}_{2} \mathrm{O}$ in the gas phase (Fig. 5c, spectrum (b)).

At $150{ }^{\circ} \mathrm{C}$ (Fig. 5b, spectrum (c)), the nitrate bands at 1,275 and $1,234 \mathrm{~cm}^{-1}$ almost vanished, which is accompanied by strong decrease in the concentration of gaseous $\mathrm{NO}_{2}$ (Fig. 5c, spectrum (c)) and increase in the amount of $\mathrm{CO}_{2}$ and $\mathrm{N}_{2} \mathrm{O}$. The intensities of the bands at 1,139 and $1,098 \mathrm{~cm}^{-1}$ (Fig. 5b, spectrum (c)) associated with the adsorbed nitroacetone and isopropoxide are reduced and they appear as unresolved absorption between 1,160 and $1,070 \mathrm{~cm}^{-1}$. The weak band at $1,050 \mathrm{~cm}^{-1}$ is assigned to the $\rho\left(\mathrm{CH}_{3}\right)$ mode of the acetate species [27] whose concentration has increased significantly. The latter is evident by the observed increase in the intensities of the bands at 1,454 and $1,420 \mathrm{~cm}^{-1}$ corresponding to the $v_{\mathrm{s}}(\mathrm{COO})$ stretching vibrations of the acetates. The absorption at $1,684 \mathrm{~cm}^{-1}$ is characteristic of the $v(\mathrm{C}=\mathrm{O})$ mode of acetone coordinated to a Lewis acid site [25-28, 31]. This assignment is supported by the spectra of acetone adsorbed between 25 and $350{ }^{\circ} \mathrm{C}$ (see below). Most likely, the acetone is formed below $150{ }^{\circ} \mathrm{C}$ simultaneously with the nitroacetone but the strong nitrate band at $1,654 \mathrm{~cm}^{-1}$ hinders the detection of the former compound. The amount of the NCO species detected under these conditions is extremely low (Fig. 5b, traces (c) and (cx2)). The changes in the spectrum taken at $200{ }^{\circ} \mathrm{C}$ (Fig. 5b, spectrum (d)) are associated with small decrease in the intensities of the absorption bands due to nitroacetone and acetone which is evident from the subtraction spectrum $(\mathrm{d}-\mathrm{c})$. This spectrum is not shown. No appreciable amount of NCO species is detected under these conditions. It should be noted that at $200{ }^{\circ} \mathrm{C}, \mathrm{NO}_{2}$ disappears from the gas phase. There is some increase in the amount of $\mathrm{CO}_{2}$ (Fig. 5c, spectrum (d)).

Between 250 and $300{ }^{\circ} \mathrm{C}$ (Fig. 5b, spectra (d) and (f)) the predominant surface species are the acetates. The surface nitrates, acetone and nitroacetone disappear at $250{ }^{\circ} \mathrm{C}$ (Fig. 5b, spectrum (e)). Further increase in the temperature results in gradual decomposition of the acetate species which is accompanied by increase in the concentration of $\mathrm{CO}_{2}$ and formation of small amount of $\mathrm{CO}$ in the gas phase (Fig. 5c, spectra (e) to (g)). At $350{ }^{\circ} \mathrm{C}, \mathrm{CO}$ disappears and $\mathrm{N}_{2} \mathrm{O}$ is detected in lower concentration. The assignment of the absorption bands observed during the interaction of the species obtained by room-temperature adsorption of $\mathrm{NO}+\mathrm{O}_{2}+\mathrm{C}_{3} \mathrm{H}_{6}$ mixture over the $25 \mathrm{NbZ}-\mathrm{P}$ catalyst is summarized in Table 3. 
Fig. 5 FT-IR spectra collected during the exposure of the $25 \mathrm{NbZ}-\mathrm{P}$ catalyst to a $(18 \mathrm{mbar}$ $\mathrm{NO}+3$ mbar $_{3} \mathrm{H}_{6}+10$ mbar $\mathrm{O}_{2}$ ) mixture at room temperature for $20 \mathrm{~min}$ followed by evacuation for $10 \mathrm{~min}(a)$ and heating the isolated IR cell for $15 \mathrm{~min}$ at $100{ }^{\circ} \mathrm{C}(b), 150{ }^{\circ} \mathrm{C}(c), 200{ }^{\circ} \mathrm{C}$ (d), $250{ }^{\circ} \mathrm{C}(e), 300{ }^{\circ} \mathrm{C}(f)$ and $350{ }^{\circ} \mathrm{C}(\mathrm{g})$. FT-IR spectra of the catalyst recorded in the $4,000-2,500 \mathrm{~cm}^{-1}$ region (Panel a), 2,500-980 $\mathrm{cm}^{-1}$ region (Panel b) and gas phase spectra (Panel c)
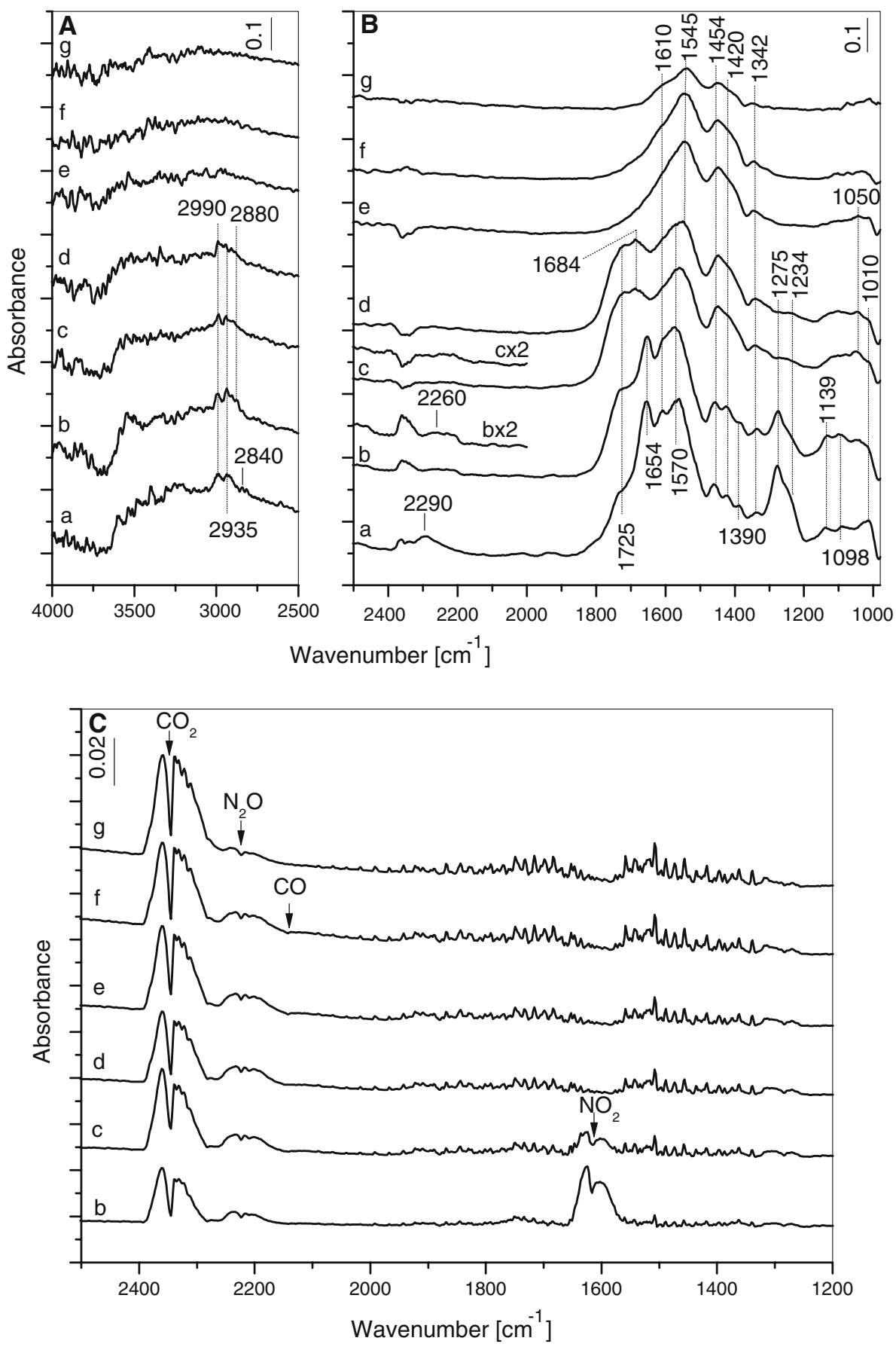

The disappearance of $\mathrm{NO}_{2}$ from the spectrum taken at $200{ }^{\circ} \mathrm{C}$ is in strong contrast with the results of the thermal stability of the nitrate species in the absence of propene (see Fig. 3). In the latter experiment gaseous $\mathrm{NO}_{2}$ was observed in the whole temperature range between 100 and $350{ }^{\circ} \mathrm{C}$. This difference suggests that the $\mathrm{NO}_{3}{ }^{-}$species, respectively activated $\mathrm{NO}_{2}$ surface complex, react with the adsorbed propene and/or hydrocarbon oxygenates.

\subsubsection{Adsorption of Acetone and its Interaction with $\mathrm{NO}_{2}$ Over the 25NbZ-P Catalyst}

In order to confirm the assignment of the absorption band at $1,725 \mathrm{~cm}^{-1}$ (Fig. 5b) to adsorbed nitroacetone, we investigated the adsorption of acetone and its interaction with $\mathrm{NO}_{2}$ at elevated temperatures.

The adsorption of $1 \mathrm{mbar}$ of acetone on the $25 \mathrm{NbZ}-\mathrm{P}$ sample at room temperature followed by evacuation for 
Table 3 Assignment of the absorption bands observed during the investigation of the reactivity of surface species formed upon roomtemperature adsorption of $\mathrm{NO}+\mathrm{C}_{3} \mathrm{H}_{6}+\mathrm{O}_{2}$ mixture on the $25 \mathrm{NbZ}$ $\mathrm{P}$ catalyst in the $25-350{ }^{\circ} \mathrm{C}$ temperature range

\begin{tabular}{|c|c|c|}
\hline Species & $\begin{array}{l}\text { Band position } \\
\left(\mathrm{cm}^{-1}\right)\end{array}$ & Vibration \\
\hline \multirow{2}{*}{$\begin{array}{l}\text { Isopropoxide (two } \\
\text { types) }\end{array}$} & $2,990,2,935$ & $v_{\text {as }}\left(\mathrm{CH}_{3}\right), v_{\mathrm{s}}\left(\mathrm{CH}_{3}\right)$ \\
\hline & $1,098,1,010$ & $v(\mathrm{C}-\mathrm{O})$ \\
\hline \multirow[t]{3}{*}{ Acetone (ads) } & $2,990,2,935$ & $v_{\mathrm{as}}\left(\mathrm{CH}_{3}\right), v_{\mathrm{s}}\left(\mathrm{CH}_{3}\right)$ \\
\hline & 1,684 & $v(\mathrm{C}=\mathrm{O})$ \\
\hline & 1,139 & $\delta(\mathrm{CCC})$ \\
\hline \multirow[t]{4}{*}{ Nitroacetone (ads) } & $2,990,2,935$ & $v_{\mathrm{as}}\left(\mathrm{CH}_{3}\right), v_{\mathrm{s}}\left(\mathrm{CH}_{3}\right)$ \\
\hline & 2,880 & $v\left(\mathrm{CH}_{2}\right)$ \\
\hline & 1,725 & $v(\mathrm{C}=\mathrm{O})$ \\
\hline & 1,139 & $\delta(\mathrm{CCC})$ \\
\hline Bridged $\mathrm{NO}_{3}^{-}$ & $1,654,1,234,1,010$ & $\begin{array}{c}v(\mathrm{~N}=\mathrm{O}), v_{\mathrm{as}}\left(\mathrm{NO}_{2}\right), \\
v_{\mathrm{s}}\left(\mathrm{NO}_{2}\right)\end{array}$ \\
\hline Bidentate $\mathrm{NO}_{3}{ }^{-}$ & $1,570,1,275,1,010$ & $\begin{array}{c}v(\mathrm{~N}=\mathrm{O}), v_{\mathrm{as}}\left(\mathrm{NO}_{2}\right), \\
v_{\mathrm{s}}\left(\mathrm{NO}_{2}\right)\end{array}$ \\
\hline \multirow{3}{*}{$\begin{array}{l}\mathrm{CH}_{3} \mathrm{COO}^{-} \text {(two } \\
\text { types) }\end{array}$} & $1,610,1,545$ & $v_{\mathrm{as}}(\mathrm{COO})$ \\
\hline & $1,420,1,454$ & $v_{\mathrm{s}}(\mathrm{COO})$ \\
\hline & $1,342,1,050$ & $\delta\left(\mathrm{CH}_{3}\right), \rho\left(\mathrm{CH}_{3}\right)$ \\
\hline $\mathrm{NCO}$ & 2,290 & $v_{\mathrm{as}}(\mathrm{NCO})$ \\
\hline
\end{tabular}

15 min, results in spectrum (a) shown in Fig. 6. The strong band at $1,687 \mathrm{~cm}^{-1}$ corresponds to the $v(\mathrm{C}=\mathrm{O})$ stretching vibration of adsorbed acetone [25-28, 31]. This band is red-shifted as compared with the $v(\mathrm{C}=\mathrm{O})$ stretching vibration of gaseous acetone and indicates that the molecule is coordinated to a Lewis acid site [25]. The intensities

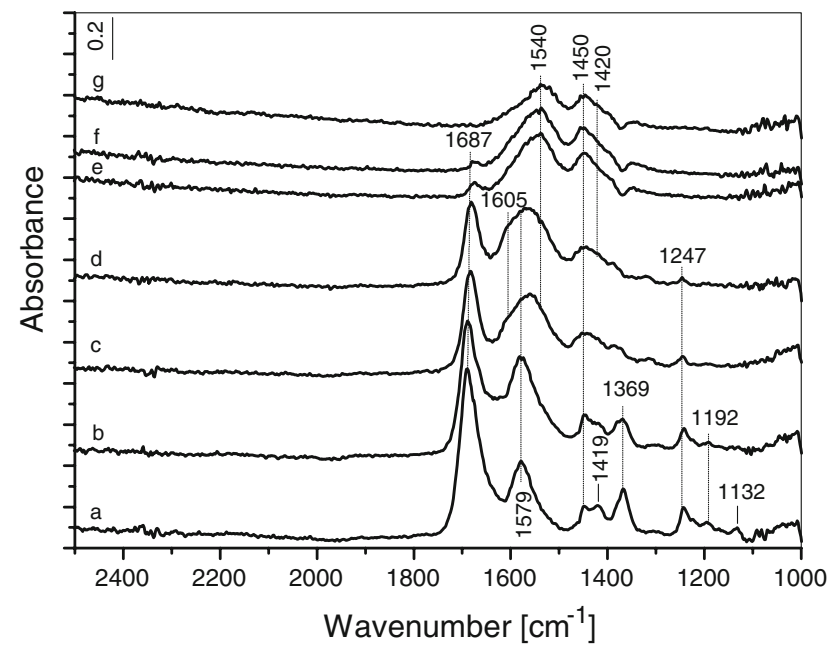

Fig. 6 FT-IR spectra of acetone (1 mbar) adsorbed on the 25NbZ-P catalyst for $10 \mathrm{~min}$ at room temperature followed by evacuation for $10 \mathrm{~min}(a)$ and after heating the isolated IR cell for $15 \mathrm{~min}$ at $100{ }^{\circ} \mathrm{C}$ (b), $150{ }^{\circ} \mathrm{C}(c), 200{ }^{\circ} \mathrm{C}(d), 250{ }^{\circ} \mathrm{C}(e), 300{ }^{\circ} \mathrm{C}(f)$ and $350{ }^{\circ} \mathrm{C}(g)$ of the bands at $1,419,1,369,1,247,1,192$, and $1,132 \mathrm{~cm}^{-1}$ decrease with the temperature simultaneously with the absorption at $1,687 \mathrm{~cm}^{-1}$. Therefore, all these bands are attributed to various vibrational modes of the adsorbed acetone (see Table 4). The bands at 1,579 and $1,450 \mathrm{~cm}^{-1}$ observed in spectrum (a) are best assigned to bidentate acetates and correspond to the $v_{\mathrm{as}}(\mathrm{COO})$ and $v_{\mathrm{s}}(\mathrm{COO})$ modes, respectively [26-28, 31]. This experimental fact indicates that the $25 \mathrm{NbZ}-\mathrm{P}$ catalyst is able to oxidize the adsorbed acetone already at room temperature. Heating the isolated IR cell for $15 \mathrm{~min}$ at $100{ }^{\circ} \mathrm{C}$, leads to increase in the amount of the acetates at 1,579 and $1,450 \mathrm{~cm}^{-1}$ at the expense of adsorbed acetone (Fig. 6, spectrum (b)). At 150 (spectrum (c)) and $200{ }^{\circ} \mathrm{C}$ (spectrum (d)), the population of the $\mathrm{CH}_{3} \mathrm{COO}^{-}$species grows further. This is evident by the appearance of poorly resolved absorptions at approximately 1,604 and $1,540 \mathrm{~cm}^{-1}$ assigned to the $v_{\text {as }}(\mathrm{COO})$ modes of two new acetate species. The oxidation of acetone occurs in great extent at temperatures higher than $200{ }^{\circ} \mathrm{C}$ which is evident by the significant increase in the concentration of the acetate species at $250{ }^{\circ} \mathrm{C}$ (Fig. 6, spectrum (e)). The heating at $350{ }^{\circ} \mathrm{C}$ (spectrum (g)) does not lead to their complete removal, the acetates at $1,540 \mathrm{~cm}^{-1}$ being the most stable. Adsorbed acetone is observed up to $300{ }^{\circ} \mathrm{C}$ (spectrum (f)). The assignment of the absorption bands is summarized in Table 4 .

Table 4 Assignments of the absorption bands in the spectra observed during the high-temperature adsorption of acetone and its coadsorption with $\mathrm{NO}_{2}$ on the 25NbZ-P catalyst

\begin{tabular}{|c|c|c|}
\hline Species & $\begin{array}{l}\text { Band position } \\
\left(\mathrm{cm}^{-1}\right)\end{array}$ & Vibration \\
\hline \multirow[t]{6}{*}{ Acetone (ads) } & $2,985,2,925$ & $v_{\mathrm{as}}\left(\mathrm{CH}_{3}\right), v_{\mathrm{s}}\left(\mathrm{CH}_{3}\right)$ \\
\hline & $1,690-1,687$ & $v(\mathrm{C}=\mathrm{O})$ \\
\hline & $1,419-1,417$ & $\delta_{\mathrm{as}}\left(\mathrm{CH}_{3}\right)$ \\
\hline & $1,370-1,369$ & $\delta_{\mathrm{s}}\left(\mathrm{CH}_{3}\right)$ \\
\hline & $1,247,1,192$ & $v_{\mathrm{as}}(\mathrm{CCC}), v_{\mathrm{s}}(\mathrm{CCC})$ \\
\hline & 1,139 & $\delta(\mathrm{CCC})$ \\
\hline \multirow[t]{4}{*}{ Nitroacetone (ads) } & $2,985,2,925$ & $v_{\mathrm{as}}\left(\mathrm{CH}_{3}\right), v_{\mathrm{s}}\left(\mathrm{CH}_{3}\right)$ \\
\hline & 2,885 & $v\left(\mathrm{CH}_{2}\right)$ \\
\hline & 1,735 & $v(\mathrm{C}=\mathrm{O})$ \\
\hline & 1,130 & $\delta(\mathrm{CCC})$ \\
\hline Bridged $\mathrm{NO}_{3}{ }^{-}$ & $1,660,1,250,1,010$ & $\begin{array}{l}v(\mathrm{~N}=\mathrm{O}), v_{\mathrm{as}}\left(\mathrm{NO}_{2}\right) \\
\quad v_{\mathrm{s}}\left(\mathrm{NO}_{2}\right)\end{array}$ \\
\hline Bidentate $\mathrm{NO}_{3}^{-}$ & $1,573,1,276,1,010$ & $\begin{array}{l}v(\mathrm{~N}=\mathrm{O}), v_{\mathrm{as}}\left(\mathrm{NO}_{2}\right) \\
\quad v_{\mathrm{s}}\left(\mathrm{NO}_{2}\right)\end{array}$ \\
\hline \multirow{3}{*}{$\begin{array}{l}\text { Bidentate } \mathrm{CH}_{3} \mathrm{COO}^{-} \\
\text {(two types) }\end{array}$} & $1,615-1,579,1,540$ & $v_{\mathrm{as}}(\mathrm{COO})$ \\
\hline & $\begin{array}{c}1,417-1,410 \\
1,453-1,450\end{array}$ & $v_{\mathrm{s}}(\mathrm{COO})$ \\
\hline & 1,350 & $\delta\left(\mathrm{CH}_{3}\right)$ \\
\hline $\mathrm{NCO}$ & 2,260 & $v_{\mathrm{as}}(\mathrm{NCO})$ \\
\hline
\end{tabular}


The spectra shown in Fig. 7 are obtained during the interaction of $\mathrm{NO}_{2}$ in the $25-350{ }^{\circ} \mathrm{C}$ temperature range with acetone adsorbed at room temperature on the surface of the 25NbZ-P sample. The activated sample was left in contact with 1 mbar of acetone for $10 \mathrm{~min}$ at room temperature followed by evacuation for $10 \mathrm{~min}$. Then to the IR cell 1.4 mbar of $\mathrm{NO}_{2}$ were added and the isolated IR cell containing gaseous $\mathrm{NO}_{2}$ was heated between 25 and
$350{ }^{\circ} \mathrm{C}$ for $15 \mathrm{~min}$ at each temperature. The spectrum detected at room temperature (Fig. 7a, spectrum (a)) contains bands at 2,985 and $2,925 \mathrm{~cm}^{-1}$ due to the $v_{\text {as }}\left(\mathrm{CH}_{3}\right)$ and $v_{\mathrm{s}}\left(\mathrm{CH}_{3}\right)$ modes of adsorbed acetone. The latter compound gives rise to the bands at 1,690 $(v(\mathrm{C}=\mathrm{O})), 1,417\left(\delta_{\mathrm{as}}\left(\mathrm{CH}_{3}\right)\right)$ and $1,370 \mathrm{~cm}^{-1}\left(\delta_{\mathrm{s}}\left(\mathrm{CH}_{3}\right)\right)$ in the $1,700-1,000 \mathrm{~cm}^{-1}$ region (Fig. $7 \mathrm{~b}$, spectrum (a)). The weak absorption at $1,453 \mathrm{~cm}^{-1}$ suggests formation of
Fig. 7 FT-IR spectra of adsorbed acetone (1 mbar) on the $25 \mathrm{NbZ}-\mathrm{P}$ catalyst for $10 \mathrm{~min}$ at room temperature followed by evacuation for $10 \mathrm{~min}$ and addition of 1.4 mbar $\mathrm{NO}_{2}(a)$ and heating the isolated IR cell for $15 \mathrm{~min}$ at $100{ }^{\circ} \mathrm{C}(b)$, $150{ }^{\circ} \mathrm{C}(c), 200{ }^{\circ} \mathrm{C}(d), 250{ }^{\circ} \mathrm{C}$ $(e), 300{ }^{\circ} \mathrm{C}(f)$ and $350{ }^{\circ} \mathrm{C}(\mathrm{g})$. FT-IR spectra of the catalyst recorded in the 4,000$2,500 \mathrm{~cm}^{-1}$ region (Panel a) and $2,500-1,000 \mathrm{~cm}^{-1}$ region (Panel b) and gas phase spectra (Panel c)
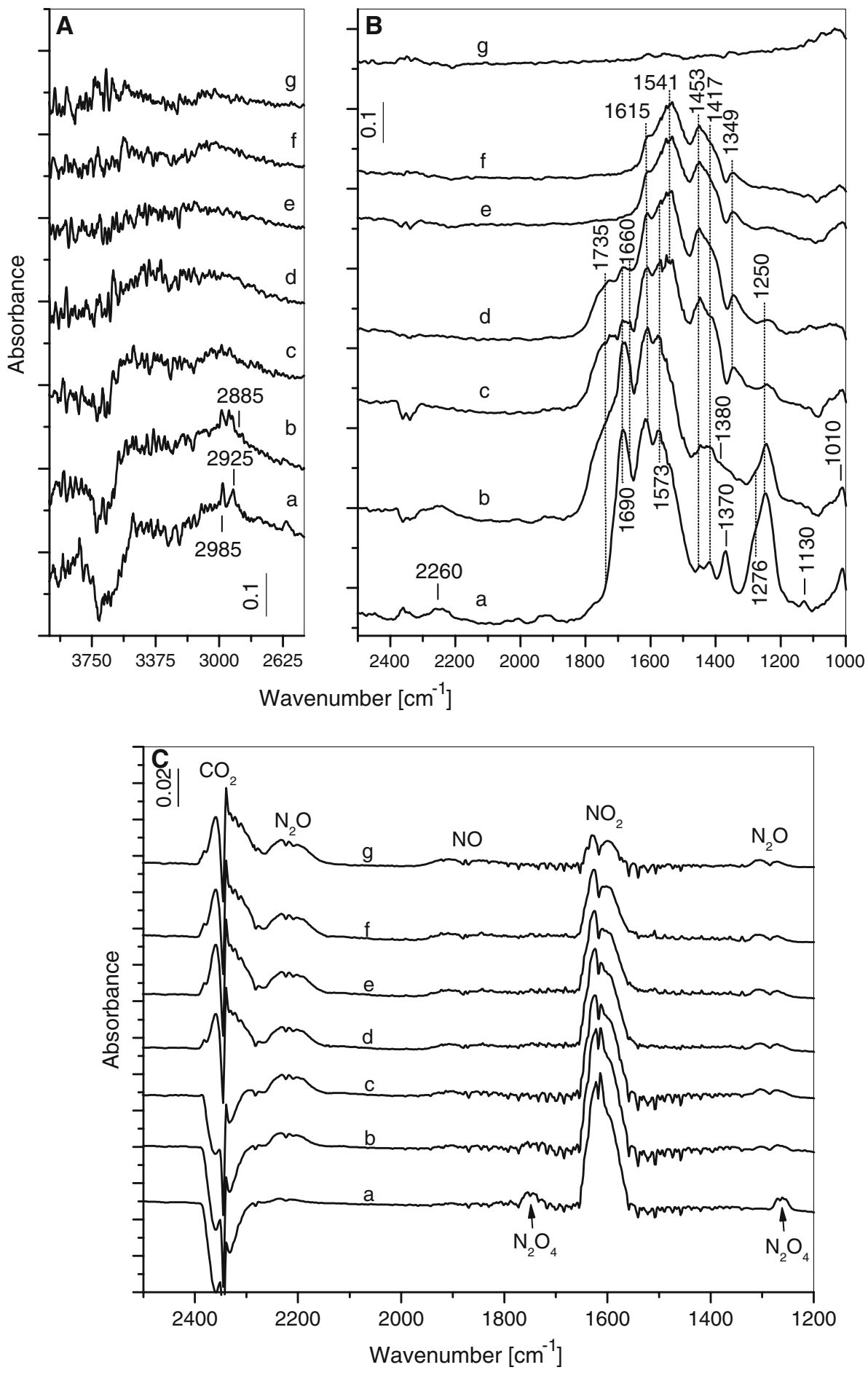
acetate species and is attributed to the $v_{\mathrm{s}}(\mathrm{COO})$ mode. As shown above, the bands at 1,660 and $1,250 \mathrm{~cm}^{-1}$ and at 1,573 and $1,276 \mathrm{~cm}^{-1}$ are due mainly to bridged and bidentate nitrate species $\left(v(\mathrm{~N}=\mathrm{O})\right.$ and $v_{\mathrm{as}}\left(\mathrm{NO}_{2}\right)$ modes $)$. Weak band with maximum at $2,260 \mathrm{~cm}^{-1}$ and shoulder at approximately $1,735 \mathrm{~cm}^{-1}$ are detected. As in the case of adsorbed acetone in the absence of $\mathrm{NO}_{2}$ (Fig. 6), the increase in the temperature to $100{ }^{\circ} \mathrm{C}$ causes increase in the amount of acetate species, which is evident by the enhancement of the intensities of the bands at 1,453 and $1,417 \mathrm{~cm}^{-1}$ (Fig. 7b, spectrum (b)). In addition, there is a strong increase of the absorption at $1,735 \mathrm{~cm}^{-1}$ and decrease in the intensity of the band at $2,260 \mathrm{~cm}^{-1}$. The latter two bands are not observed during the adsorption of acetone in the absence of $\mathrm{NO}_{2}$ (see Fig. 6). This confirms the assumption made above that the absorption at $1,735 \mathrm{~cm}^{-1}$ corresponds to nitroacetone and its transformation leads to the generation of NCO species giving rise to the absorption at $2,260 \mathrm{~cm}^{-1}$. The formation of nitroacetone from acetone is supported by the observed strong decrease in the intensity of the band at $1,370 \mathrm{~cm}^{-1}$ due to the $\delta_{\mathrm{s}}\left(\mathrm{CH}_{3}\right)$ mode of adsorbed acetone (Fig. 7b, spectrum (b)) and appearance of a pronounced shoulder at $2,885 \mathrm{~cm}^{-1}$ corresponding to the $v\left(v \mathrm{CH}_{2}\right)$ stretching vibration (Fig. 7a, spectrum (b)). This indicates that substitution of hydrogen atom(s) in the methyl group(s) of acetone for nitro group(s) has occurred.

The development of the absorption bands between 150 and $350{ }^{\circ} \mathrm{C}$ is analogous to that observed during the adsorption of $\mathrm{NO}+\mathrm{C}_{3} \mathrm{H}_{6}+\mathrm{O}_{2}$ mixture on the surface of the $25 \mathrm{NbZ}-\mathrm{P}$ catalyst (compare with Fig. $5 \mathrm{~b}$ ). However, no $\mathrm{NCO}$ species are detected at $150{ }^{\circ} \mathrm{C}$ in the presence of gaseous $\mathrm{NO}_{2}$ (compare spectra (c) in Figs. 5b, 7b). The acetone and its nitro substituent disappear from the surface of $25 \mathrm{NbZ}-\mathrm{P}$ sample at $250{ }^{\circ} \mathrm{C}$ (Fig. $7 \mathrm{~b}$, spectrum (e)). The spectra detected at this temperature and $300{ }^{\circ} \mathrm{C}$ (spectrum (f)) contain bands due mainly to adsorbed acetate species $\left(1,615,1,541,1,453,1,417\right.$, and $\left.1,349 \mathrm{~cm}^{-1}\right)$. The decomposition of surface acetates begins at $250{ }^{\circ} \mathrm{C}$, which causes decrease in their concentration and disappearance at $350{ }^{\circ} \mathrm{C}$. The spectra of the gas phase taken between 25 and $350{ }^{\circ} \mathrm{C}$ are shown in Fig. 7c. The amount of $\mathrm{NO}_{2}$ gradually decreases with the temperature which could be attributed to shift of the equilibrium $\mathrm{NO}_{2} \leftrightarrow \mathrm{NO}+0.5 \mathrm{O}_{2}$ to the right and interaction of $\mathrm{NO}_{2}$ with the adsorbed acetone, nitroacetone and NCO species. The latter processes account for the formation of significant amount of $\mathrm{CO}_{2}$ at $200{ }^{\circ} \mathrm{C}$ (Fig. 7c, spectrum (d)).

Table 4, 5 summarizes the assignment of the absorption bands observed in the spectra detected during the adsorption of acetone and its co-adsorption with $\mathrm{NO}_{2}$ on the 25NbZ-P sample.
Table 5 Assignment of the absorption bands observed during the investigation of the reactivity of surface species formed upon roomtemperature adsorption of $\mathrm{NO}+\mathrm{C}_{3} \mathrm{H}_{6}+\mathrm{O}_{2}$ mixture on the $0.1 \mathrm{Pd} /$ 25NbZ-P catalyst in the $25-350{ }^{\circ} \mathrm{C}$ temperature range

\begin{tabular}{|c|c|c|}
\hline Species & $\begin{array}{l}\text { Band position } \\
\left(\mathrm{cm}^{-1}\right)\end{array}$ & Vibration \\
\hline \multirow{2}{*}{$\begin{array}{r}\text { Isopropoxide } \\
\text { (two types) }\end{array}$} & $2,990,2,930$ & $v_{\mathrm{as}}\left(\mathrm{CH}_{3}\right), v_{\mathrm{s}}\left(\mathrm{CH}_{3}\right)$ \\
\hline & $1,094,1,010$ & $v(\mathrm{C}-\mathrm{O})$ \\
\hline \multirow[t]{3}{*}{ Acetone (ads) } & $2,990,2,930$ & $v_{\mathrm{as}}\left(\mathrm{CH}_{3}\right), v_{\mathrm{s}}\left(\mathrm{CH}_{3}\right)$ \\
\hline & 1,686 & $v(\mathrm{C}=\mathrm{O})$ \\
\hline & $1,332,1,138$ & $\delta_{\mathrm{s}}\left(\mathrm{CH}_{3}\right), \delta(\mathrm{CCC})$ \\
\hline \multirow{3}{*}{$\begin{array}{l}\text { Nitroacetone } \\
\quad \text { (ads) }\end{array}$} & $2,990,2,930$ & $v_{\mathrm{as}}\left(\mathrm{CH}_{3}\right), v_{\mathrm{s}}\left(\mathrm{CH}_{3}\right)$ \\
\hline & 1,730 & $v(\mathrm{C}=\mathrm{O})$ \\
\hline & $1,332,1,138$ & $\delta_{\mathrm{s}}\left(\mathrm{CH}_{3}\right), \delta(\mathrm{CCC})$ \\
\hline Bridged $\mathrm{NO}_{3}{ }^{-}$ & $1,656,1,250,1,010$ & $\begin{array}{c}v(\mathrm{~N}=\mathrm{O}), v_{\text {as }}\left(\mathrm{NO}_{2}\right) \\
v_{\mathrm{s}}\left(\mathrm{NO}_{2}\right)\end{array}$ \\
\hline Bidentate $\mathrm{NO}_{3}{ }^{-}$ & $1,573,1,279,1,010$ & $\begin{array}{c}v(\mathrm{~N}=\mathrm{O}), v_{\mathrm{as}}\left(\mathrm{NO}_{2}\right) \\
v_{\mathrm{s}}\left(\mathrm{NO}_{2}\right)\end{array}$ \\
\hline \multirow{3}{*}{$\begin{array}{l}\mathrm{CH}_{3} \mathrm{COO}^{-} \\
\quad \text { (two types) }\end{array}$} & $1,593,1,553$ & $v_{\mathrm{as}}(\mathrm{COO})$ \\
\hline & $1,457,1,422$ & $v_{\mathrm{s}}(\mathrm{COO})$ \\
\hline & $1,346,1,053$ & $\delta\left(\mathrm{CH}_{3}\right), \rho\left(\mathrm{CH}_{3}\right)$ \\
\hline $\mathrm{NCO} / \mathrm{Zr}_{6} \mathrm{Nb}_{2} \mathrm{O}_{17}$ & 2,290 & $v_{\mathrm{as}}(\mathrm{NCO})$ \\
\hline Pd-NCO & 2,182 & $v_{\mathrm{as}}(\mathrm{NCO})$ \\
\hline
\end{tabular}

\section{Discussion}

The FT-IR spectra obtained during the adsorption of $\left(\mathrm{NO}+\mathrm{C}_{3} \mathrm{H}_{6}+\mathrm{O}_{2}\right.$ ) and (acetone $+\mathrm{NO}_{2}$ ) mixtures on the $25 \mathrm{NbZ}-\mathrm{P}$ catalyst show formation of $\mathrm{NCO}$ species already at room temperature. The surface isocyanates are considered to be reactive intermediates in the selective reduction of $\mathrm{NO}_{x}$ with hydrocarbons [4-6, 39-46]. In the case of supported copper catalysts, which are among the most active non-noble metal oxide catalysts in the selective reduction of $\mathrm{NO}_{x}$ with propene, the formation of NCO species is detected at higher temperatures $\left(150-250{ }^{\circ} \mathrm{C}\right)[34,39,42,43,47-49]$. Their generation through transformation of organic nitro compound, $\mathrm{C}_{x} \mathrm{H}_{y} \mathrm{NO}_{z}$, has been proposed for various catalytic systems [4-6, 35-37, 40, 43, 46, 48-53]. Our experiments with nitropropane show that this compound immediately isomerizes to nitritopropane upon adsorption on the $25 \mathrm{NbZ}$ $\mathrm{P}$ sample at room temperature (the spectra are not shown). The heating between 100 and $350{ }^{\circ} \mathrm{C}$ causes the oxidation of the adsorbed nitritopropane to surface acetates and above $200{ }^{\circ} \mathrm{C}$ the spectra contain only the characteristic bands of the latter species. No NCO groups are detected in the whole temperature range. Therefore, it can be proposed that the source of isocyanates over the $25 \mathrm{NbZ}-\mathrm{P}$ sample is the nitroacetone. Pearson et al. [54] have shown that in a weak basic medium nitroacetone produces aci-anion of nitromethane $\left(\mathrm{CH}_{2} \mathrm{NO}_{2}{ }^{-}\right)$and acetate species. The former 
compound in turn can transform into NCO groups [4, 37, 46, $52,53]$. Most likely, the decomposition of nitroacetone to aci-nitromethane and $\mathrm{CH}_{3} \mathrm{COO}^{-}$species occurs on basic $\mathrm{O}^{2-}$ sites of the $25 \mathrm{NbZ}-\mathrm{P}$ sample:

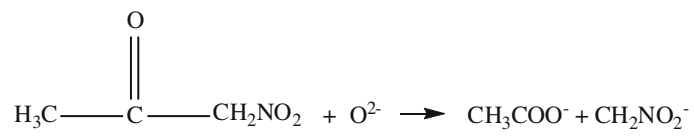

The characteristic vibrations of aci-nitromethane fall in the $1,650-1,200 \mathrm{~cm}^{-1}$ region $[37,52,53]$ and if they are present, they cannot be located due to overlapping with the nitrate-carboxylate bands. However, the product of acinitromethane transformation, the NCO species, is clearly observable at $2,290-2,260 \mathrm{~cm}^{-1}$ in the spectra taken at 25 and $100{ }^{\circ} \mathrm{C}$ (Figs. 5b, 7b, spectra (a) and (b)). It is well known that the surface isocyanates react easily with $\mathrm{NO}+\mathrm{O}_{2}$ mixtures and/or $\mathrm{NO}_{2}$ yielding molecular nitrogen and $\mathrm{N}_{2} \mathrm{O}$ as reaction products $[4-6,34,35,38,41,43,50]$. This fact can account for the disappearance of the NCO species and $\mathrm{NO}_{2}$ at temperatures higher than $100-150{ }^{\circ} \mathrm{C}$. Therefore, we are of the opinion that the low-temperature activity the $25 \mathrm{NbZ}-\mathrm{P}$ catalyst is associated with the nature of the organic nitro compound formed during the course of the reaction. Most probably the transformation route of nitropropane to isocyanate species over the majority of oxidebased catalysts is energetically more expensive than that of nitroacetone via aci-nitromethane to $\mathrm{NCO}$ as proposed for the $25 \mathrm{NbZ}-\mathrm{P}$ catalyst.

The experimental results show that the nitroacetone and acetone disappear simultaneously at $250{ }^{\circ} \mathrm{C}$ (Figs. 5b, 7b, spectrum (e)). It can be proposed that under these conditions both compounds are further oxidized to acetates. The latter species begin to decompose at $250{ }^{\circ} \mathrm{C}$ causing an increase in the amount of $\mathrm{CO}_{2}$ (Figs. 5c, 7c, spectrum (e)). It seems that the nitroacetone and acetone have the same thermal stability when adsorbed on the $25 \mathrm{NbZ}-\mathrm{P}$ catalyst. As shown above, the oxidation of adsorbed acetone to $\mathrm{CH}_{3} \mathrm{COO}^{-}$species occurs in large extent at $250{ }^{\circ} \mathrm{C}$ (see Fig. 6). In other words, we assume that the nitroacetone can undergo transformations through two parallel reactions: path (1) consisting of acid-base reaction (reaction 1) and path (2) involving the oxidation of nitroacetone. The latter process is important most likely at temperatures higher than $200{ }^{\circ} \mathrm{C}$. The products of high-temperature transformation of nitroacetone would be $\mathrm{NO}_{x}$ species, presumably $\mathrm{NO}_{2}$ or surface nitrate, in addition to the acetates and $\mathrm{CO}_{x} / \mathrm{H}_{2} \mathrm{O}$. The $\mathrm{NO}_{2} / \mathrm{NO}_{3}{ }^{-}$surface complex formed in path (2) can be involved in interactions with propene and/or surface isocianates.

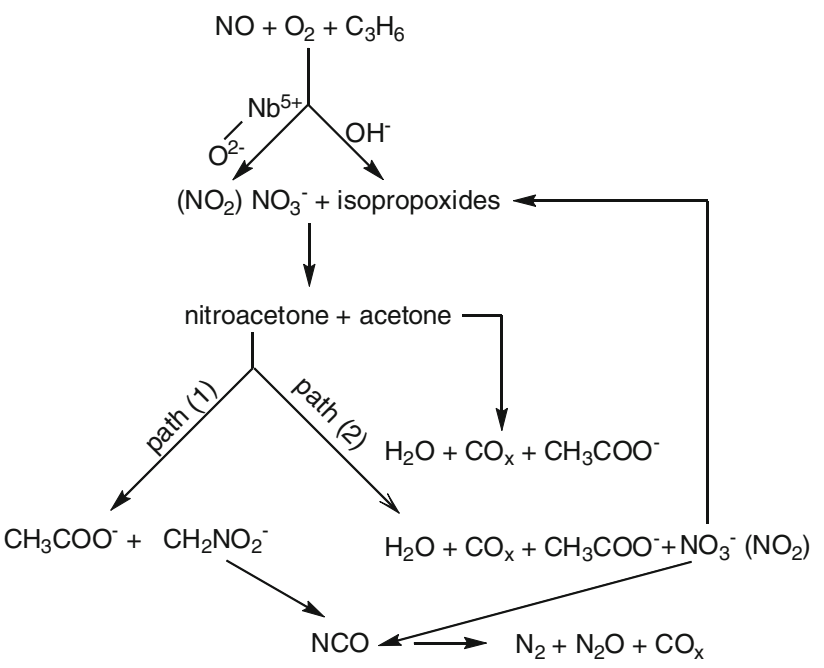

Scheme 1

A mechanism for the surface reaction of propene and $\mathrm{NO}_{x}$ species adsorbed on the $25 \mathrm{NbZ}-\mathrm{P}$ catalyst, deduced from the in situ FT-IR measurements, is proposed in Scheme 1.

It is assumed that the interaction of the isopropoxide species with the surface nitrates or/and activated $\mathrm{NO}_{2}$ generates the nitroacetone. It should be noted that it is difficult to present direct evidence that the NCO species react with the surface $\mathrm{NO}_{3}{ }^{-} / \mathrm{NO}_{2}$ complexes. The experimental results show that the $\mathrm{NCO}$ species are somewhat more stable in the absence of gaseous $\mathrm{NO}_{2}$ and they produce a very weak band between 2,300 and $2,150 \mathrm{~cm}^{-1}$ at $150{ }^{\circ} \mathrm{C}$ (Fig. 5b, spectrum (c)). This absorption is absent in the spectrum taken at $150{ }^{\circ} \mathrm{C}$ upon $\mathrm{NO}_{2}$ atmosphere (Fig. 7b, spectrum c) implying that the isocyanates react with $\mathrm{NO}_{2}$ or activated $\mathrm{NO}_{2}$ surface complex. Although the experimental conditions of the FT-IR investigation and catalytic test are different, it can be proposed that the nitroacetone and isocyanates could be the main reaction intermediates. This is supported by the facts that the NCO consumption is observed by in situ FT-IR spectroscopy already at $100{ }^{\circ} \mathrm{C}$ and the $\mathrm{NO}_{x}$ reduction over the $25 \mathrm{NbZ}-\mathrm{P}$ catalyst with propene is significant at $180{ }^{\circ} \mathrm{C}\left(\sim 30 \%\right.$ of $\mathrm{NO}_{x}$ conversion). This assumption is in agreement with the currently accepted general mechanism of HC-SCR of $\mathrm{NO}_{x}$ [4-6] in which the participation of NCO species formed via organonitrogen compound is observed more readily under static conditions [35].

\section{Conclusions}

We have investigated the potential of niobium-zirconium mixed oxide as low-temperature catalysts for the SCR of $\mathrm{NO}_{x}$ with propene in excess oxygen. The mixed oxide was 
prepared by impregnation of hydrated zirconia with acidic solution $(\mathrm{pH}$ 0.5) of peroxoniobium $(\mathrm{V})$ complex, $\left[\mathrm{Nb}_{2}\left(\mathrm{O}_{2}\right)_{3}\right]^{4+}$, ensuring $\mathrm{ZrO}_{2}: \mathrm{Nb}_{2} \mathrm{O}_{5}$ mole ratio of $6: 1$. The calcined sample (denoted as $25 \mathrm{NbZ}-\mathrm{P}$ ) has the structure of $\mathrm{Zr}_{6} \mathrm{Nb}_{2} \mathrm{O}_{17}$. According to the catalytic test, the conversion of $\mathrm{NO}_{x}$ over the $25 \mathrm{NbZ}-\mathrm{P}$ catalyst passes through a maximum at $220{ }^{\circ} \mathrm{C}$. The results of detailed in situ FT-IR investigation have shown that over the $25 \mathrm{NbZ}-\mathrm{P}$ sample, characterized by strong Brønsted acidity, the activation of propene in the presence of adsorbed $\mathrm{NO}_{x}$ species is quite easy at low temperatures, producing surface isopropoxides. The interaction of the latter species with the surface nitrate complexes leads to the formation of nitroacetone. It is proposed that nitroacetone transforms through two parallel reactions: (1) with the involvement of basic oxide sites of the catalyst producing acetate species and aci-nitromethane (path (1)) and (2) oxidation to acetates and $\mathrm{CO}_{x} / \mathrm{H}_{2} \mathrm{O}$ with release of $\mathrm{NO}_{2}$ (path (2)). The latter process is important at temperatures higher than $200{ }^{\circ} \mathrm{C}$. The aci-nitromethane generates NCO species coordinated to the cationic sites of the mixed oxide. The surface isocyanates are detected already at room temperature. It is proposed that the isocyanates react with the $\mathrm{NO}_{3}{ }^{-}$/ $\mathrm{NO}_{2}$ surface complex formed by both oxidation of $\mathrm{NO}$ and oxidation of nitroacetone. The facts that the NCO consumption is observed by in situ FT-IR spectroscopy already at $100{ }^{\circ} \mathrm{C}$ and the $\mathrm{NO}_{x}$ reduction over the $25 \mathrm{NbZ}-\mathrm{P}$ catalyst is significant at $180{ }^{\circ} \mathrm{C}$ suggest that the nitroacetone and isocyanates could be the main reaction intermediates. The results of the investigation show that the catalytic properties of the $\mathrm{Zr}_{6} \mathrm{Nb}_{2} \mathrm{O}_{17}$ solid solution could be of interest regarding the development of noble metal-free, low-temperature catalyst for the $\mathrm{SCR}$ of $\mathrm{NO}_{x}$ with hydrocarbons.

Acknowledgments This work was financially supported by Bilkent University and the Scientific and Technical Research Council of Turkey (TÜBITAK), Project TBAG-106T081. I. C. and M. K. gratefully acknowledge the support by UNAM-REGPOT project under contract number 203953.

\section{References}

1. Heck RM, Farrauto RJ (2001) Appl Catal A 221:443

2. Kaŝpar J, Fornasiero P, Hickey N (2003) Catal Today 77:419

3. Iwamoto M (2000) In: Corma A, Melo FV, Mendioroz S, and Fierro JLG (Eds) Stud Surf Sci Catal 130: 23

4. Burch R, Breen JP, Meunier FC (2002) Appl Catal B 39:283

5. Burch R (2004) Catal Rev-Sci Eng 46:271

6. Kung MC, Kung HH (2004) Top Catal 28:105

7. Nowak I, Ziolek M (1999) Chem Rev 99:3603

8. Tanabe K (2003) Catal Today 78:65

9. Mitadera J, Hinode H (2002) Appl Catal B 39:205

10. Kawai H, Hinode H (2008) React Kinet Catal Lett 93:67

11. Kikuchi T, Kumagai M (2001) J Japan Petr Inst 44:145

12. Kikuchi T, Kumagai M (2001) J Japan Petr Inst 44:340

13. Abdel-Rehim MA, dos Santos ACB, Camorim VLL, da Costa Faro A Jr (2006) Appl Catal A 305:211
14. Sobczak I, Ziolek M, Nowacka M (2005) Microp Mesopor Mater 78:103

15. Goscianska J, Bazin P, Marie O, Daturi M, Sobczak I, Ziolek M (2007) Catal Today 119:78

16. Goscianska J, Ziolek M (2008) Catal Today 137:197

17. Kantcheva M, Budunoglu H, Samarskaya O (2008) Catal Commun 9:874

18. Mestres L, Martinez-Sarrion ML, Catano O, Fernandez-Urban J (2001) Z Anorg Allg Chem 627:294

19. Laane J, Ohlsen JR (1986) Progr Inorg Chem 28:465

20. Kantcheva M, Cayirtepe I (2006) J Mol Catal A 247:88

21. Hadjiivanov KI (2000) Catal Rev-Sci Eng 42:71

22. Kantcheva M, Ciftlikli EZ (2002) J Phys Chem B 106:3941

23. Busca G, Ramis G, Lorenzelli V, Janin A, Lavalley JC (1987) Spectrochim Acta 43A:489

24. Rossi PF, Busca G, Lorenzelli V, Saur O, Lavalley JC (1987) Langmuir 3:52

25. Sanchez Escribano V, Busca G, Lorenzelli V (1990) J Phys Chem 94:8939

26. Finocchio E, Busca G, Lorenzelli V, Sanchez Escribano V (1996) J Chem Soc Faraday Trans 92:1587

27. Finocchio E, Willey RJ, Busca G, Lorenzelli V (1997) J Chem Soc Faraday Trans 93:175

28. Busca G, Finocchio E, Lorenzelli V, Ramis G, Baldi M (1999) Catal Today 49:453

29. Toda Y, Ohno T, Hatayama F, Miyata H (1999) Phys Chem Chem Phys 1:1615

30. Zaki MI, Hasan MA, Pasupulety L (2001) Langmuir 17:4025

31. Hasan MA, Zaki MI, Pasupulety L (2003) Appl Catal A 243:81

32. Adams LL, Luzzio FA (1989) J Org Chem 54:5387

33. Solymosi F, Bánsági T (1979) J Phys Chem 83:552

34. Ukisu Y, Sato S, Muramatsu G, Yoshida K (1992) Catal Lett 16:11

35. Haneda M, Kinaichi Y, Inaba M, Hamada H (1998) Catal Today $42: 127$

36. Satsuma A, Cowan AD, Cant NW, Trimm DL (1999) J Catal 181:165

37. Yamaguchi M (1997) J Chem Soc Faraday Trans 93:3581

38. Weingand T, Kuba S, Hadjiivanov K, Knözinger H (2002) J Catal 209:539

39. Li C, Bethke KA, Kung HH and Kung MC (1995) J Chem SocChem Commun 813

40. Okuhara T, Yasada H, Misono M (1997) Catal Today 35:83

41. Sumiya S, He H, Abe A, Takezawa N, Yoshida K (1998) J Chem Soc Faraday Trans 94:2217

42. Shimizu K, Kawabata H, Maeshima H, Satsuma A, Hattori T (2000) J Phys Chem B 104:2885

43. Chi Y, Chuang SSC (2000) J Catal 190:75

44. Kantcheva M (2001) J Catal 204:479

45. Kantcheva M, Samarskaya O, Ilieva L, Panataleo G, Venezia AM, Andreeva D (2009) Appl Catal B 357:159

46. Sadykov VA, Lunin VV, Matyshak VA, Paukshtis EA, Rozovskii AYa, Bulgakov NN, Ross JRH (2003) Kinet Catal 44:379

47. Radtke F, Koeppel RA, Minardi EG, Baiker A (1997) J Catal 167:127

48. Anderson JA, Marquez-Alvarez C, Lopez-Minoz MJ, RodriguezRamos I, Guerrero-Ruiz A (1997) Appl Catal B 14:189

49. Kumar PA, Reddy MP, Ju LK, Hyun-Sook B, Phil HH (2008) J Mol Catal A 291:66

50. Kameoka S, Chafik T, Ukisu Y, Miyadera T (1998) Catal Lett 51:11

51. Beloshapkin SA, Matyshak VA, Paukshtis EA, Sadykov VA, Ilyichev AN, Ukharskii AA, Lunin VV (1999) React Kinet Catal Lett 66:297

52. Zuzaniuk V, Meunier FC, Ross JRH (2001) J Catal 202:340

53. Yeom YH, Li M, Sachtler WMH, Weitz E (2006) J Catal 238:100

54. Pearson RG, Anderson DH, Alt LL (1955) J Am Chem Soc 77:527 